\title{
Utilization of Dehydrated Herbs in the Formulation of Value Added Snack "Rice Flakes Mix"
}

Ena Gupta ${ }^{1 *}$, Jyoti Sinha ${ }^{1}$ and Ritu P. Dubey ${ }^{2}$

${ }^{1}$ Sam Higginbottom Institute of Agriculture, Technology and Sciences, Allahabad, India

${ }^{2}$ Sr. Assistant Professor, Department of Foods and Nutrition, Sam Higginbottom Institute of Agriculture, Technology and Sciences, Allahabad, India

\begin{abstract}
Herbs are still the alternative medicine and primary source of health care for $80 \%$ of the world. Information available on the nutritive value of herbs is negligible. Thus, an attempt was made to introduce new types of value added edible medicinal herbs in food product, which will improve the well being of the citizen in the country and prevent micronutrient malnutrition. Low calorie ready-to-eat snack (rice flakes mix) was developed by incorporating edible dehydrated herbs, high in nutritional value and rich in micronutrients viz. mint, basil, drumstick, ginger, garlic and lotus stem. These herbs were analyzed for proximate and mineral contents which were then incorporated into rice flakes with one control $\left(T_{0}\right)$ and four treatments $T_{1}, T_{2}, T_{3}$ and $T_{4}$ at $4,8,12$ and $16 \%$ incorporation level of herbs using their standard ingredients and methods of preparation. The developed rice flakes mix was analyzed for nutrient composition and organoleptic evaluation and their results were carefully tabulated and finally these scores were compared with control. The developed herbal rice flakes mix was highly acceptable by the subjects and notable change in nutritional value of developed rice flakes mix was observed when compared to the control. Except carbohydrate and energy remarkable increase was observed in the nutrients such as protein, fat, fiber, calcium and iron in the developed rice flakes mix compared to control.
\end{abstract}

Keywords: Herbs; Rice Flakes Mix; Organoleptic Evaluation; Composition

\section{Introduction}

Snack foods have been known in the world from time immemorial. Essential vitamins, minerals and other nutrients can only be gained from food [1]. All over the world cereals are used as staple food [2]. Breakfast cereals are defined as "Processed grain formulations suitable for human consumption without further cooking". Rice flakes are the most common breakfast cereal used all over the country round the year [3]. Rice flakes is locally known by many names like aval, avalakki, poha, chivda and beaten rice, which are prepared from paddy and has been claimed as a good source of protein, fat and carbohydrate. Using some selected dehydrated herbs such as lotus stem, garlic, ginger, mint, basil and drumstick leaves in the preparation of ready-to-eat snack chivda mix are a way of value addition to this cereal grain. As these herbs are easily available, low cost and can be mixed together in any food items without causing any side effects [4]. Herbs not only enhance the taste and flavor of foods, but also increase the shelf life by being antimicrobial and antifungal [5-8].

Research has shown that herbs are beneficial for human health as it contains significant amount of micronutrients, vitamins, antioxidants, phytochemicals and fiber content that may help protect against degenerative diseases and micronutrient malnutrition [9]. Many valuable medicinal herbs are becoming rare and precious information regarding their health benefits is lost. Therefore, substitution of herbs in the preparation of rice flakes mix will increase the nutrition value and also provide health benefits to consumers [10]. The purpose of this study was to produce ready-to-eat low calorie nutritious snack rice flakes mix by incorporating edible dried herbs, along with a view to determine the organoleptic acceptability.

\section{Materials and Methods}

\section{Selection of herbs}

Six dehydrated herbs namely lotus stem, garlic, ginger, mint, basil and drumstick leaves were procured from the licensed and authorized shops of herbs. The above dehydrated herbs were cleaned and shortened for chemical analysis.

\section{Chemical analysis of dehydrated herbs}

Nutrients such as moisture, protein, fat, crude fiber, calcium and iron content of selected dehydrated herbs were analyzed. Total carbohydrate content were determined by difference method, protein by Micro-kjeldhal method using a conversion factor of 6.25 , fat by Soxhlet extraction method using petroleum ether (B.P. $60-70^{\circ} \mathrm{C}$ ), fiber by AOAC method [11], calcium content was determined by $\mathrm{KMnO}_{4}$ titration method, and iron content were estimated by the calorimetric method [12].

\section{Basic formulation of value added rice flakes mix}

The table 1 shows the composition of dehydrated herbs. The selected six dehydrated herbs viz. mint (Mentha asiatica), basil (Ocimum basilicum), drumstick leaves (Moringa oligfera), ginger (Zingiber officinale), garlic (Allium longicuspis) and lotus stem (Nelumbo nucifera) were incorporated in four treatments $\mathrm{T}_{1}, \mathrm{~T}_{2}, \mathrm{~T}_{3}$ and $\mathrm{T}_{4}$ at $4,8,12$ and $16 \%$ incorporation levels with herbs in different ratios using standard ingredients and methods of preparation. These herbs are not incorporated in standard recipe of rice flakes which is named as control $\left(\mathrm{T}_{0}\right)$.

*Corresponding author: Ena Gupta, Sam Higginbottom Institute of Agriculture Technology and Sciences, Allahabad, India, Tel: 09335866588, 09336122125 09984485500; Email: enaravish@gmail.com, jyoti.sinha82@rediffmail.com, ritupdubey2009@rediffmail.com

Received November 21, 2012; Accepted December 21, 2012; Published December 28, 2012

Citation: Gupta E, Sinha J, Dubey RP (2012) Utilization of Dehydrated Herbs in the Formulation of Value Added Snack "Rice Flakes Mix". J Food Process Techno S1-002. doi:10.4172/2157-7110.S1-002

Copyright: ( 2012 Gupta E, et al. This is an open-access article distributed under the terms of the Creative Commons Attribution License, which permits unrestricted use, distribution, and reproduction in any medium, provided the original author and source are credited. 
In this study few herbs were specifically used in different treatments like mint in treatment $T_{1}$, basil in treatment $T_{2}$ and drumstick leaves in treatment $\mathrm{T}_{3}$, because all these herbs show different sensory attributes along with different nutritional profile. The four treatments of different ratios were tried several times and evaluated by the sensory evaluation method and the best ratios were then used to prepare the product.

\section{Details of control and treatments}

Control $\left(\mathrm{T}_{0}\right)$ : Control $\mathrm{T}_{0}$ was prepared without incorporating herbs. (100\% rice flakes).

Treatment 1: It consists of $1 \%$ mint leaves, $1 \%$ garlic, $1 \%$ ginger, $1 \%$ lotus stem and $96 \%$ rice flakes.

Treatment 2: It consists of $1 \%$ basil leaves, $1 \%$ garlic, $1 \%$ ginger, $5 \%$ lotus stem and $92 \%$ rice flakes.

Treatment 3: It consists of $1 \%$ drumstick leaves, $1 \%$ garlic, $1 \%$ ginger, $9 \%$ lotus stem and $88 \%$ rice flakes.

Treatment 4: It consists of $1 \%$ drumstick leaves, $1 \%$ mint leaves, $1 \%$ basil leaves, $1 \%$ garlic, $1 \%$ ginger, $11 \%$ lotus stem and 84 percent rice flakes.

\section{Preparation of value added rice flakes mix}

Rice flakes mix was prepared by incorporating dehydrated herbs in different ratios. A teaspoon of oil is taken in a non stick wok; mustard seeds, green chilies and turmeric powder were added and roasted for a minute. Dry rice flakes, salt and dehydrated herbs namely lotus stem, garlic, ginger, mint, basil and drumstick leaves were added and all the ingredients were mixed together properly, preferably on a low flame. Then it was cooled and stored in an air tight container.

\section{Organoleptic evaluation}

The prepared rice flakes mix were served to group of 30 semi trained panelists for the evaluation of color, texture, flavor, taste and overall acceptability on a nine point hedonic scale with a scores ranging from 9 to 1 where scores 9 to 1 represented like extremely to dislike extremely. The quality parameters were quantified and the mean scores were calculated.

\begin{tabular}{|l|c|c|c|c|c|}
\hline \multirow{2}{*}{\multicolumn{1}{c|}{ Herbs }} & \multicolumn{5}{|c|}{ Rice flakes mix } \\
\cline { 2 - 6 } & $\mathbf{T}_{0}$ & $\mathbf{T}_{1}$ & $\mathbf{T}_{2}$ & $\mathbf{T}_{3}$ & $\mathbf{T}_{\mathbf{4}}$ \\
\hline Lotus stem (crushed) & - & $1 \%$ & $5 \%$ & $9 \%$ & $11 \%$ \\
\hline Drumstick leaves (crushed) & - & - & - & $1 \%$ & $1 \%$ \\
\hline Basil leaves (crushed) & - & - & $1 \%$ & - & $1 \%$ \\
\hline Mint leaves (crushed) & - & $1 \%$ & - & - & $1 \%$ \\
\hline Ginger (crushed) & - & $1 \%$ & $1 \%$ & $1 \%$ & $1 \%$ \\
\hline Garlic (crushed) & - & $1 \%$ & $1 \%$ & $1 \%$ & $1 \%$ \\
\hline Total \% of herbs incorporation & - & $\mathbf{4} \%$ & $\mathbf{8} \%$ & $\mathbf{1 2 \%}$ & $\mathbf{1 6 \%}$ \\
\hline
\end{tabular}

Table 1: Showing the dehydrated herbs composition of rice flakes mix.

\section{Nutritive value of developed rice flakes mix}

The proximate principles (energy, fat, carbohydrate, protein, fiber) and minerals like calcium and iron of the control and enriched rice flakes mix were assessed using the food composition tables [13] and analyzed value of herbs was determined by calculation method.

\section{Statistical analysis}

The data collected was tabulated and analyzed statistically with the help of approved statistical techniques. Percentage, mean scores, standard error of mean, critical difference and analysis of variance were applied.

\section{Results and Discussion}

The results obtained from the present investigation have been discussed in the following sub heads:

\section{Nutritional composition of dehydrated herbs}

Table 2, depicts nutritional composition of the six selected dehydrated herbs namely mint (Mentha asiatica), basil (Ocimum basilicum), drumstick leaves (Moringa oligfera), ginger (Zingiber officinale), garlic (Allium longicuspis) and lotus stem (Nelumbo nucifera). Results showed that moisture, fat, protein, carbohydrate, energy and fiber contents (\%) of the dehydrated herbs ranged between 5.20 to 11.3 g, 0.76-5.91 g, 4.06 g-19.85 g, 38.1-72.71, 205-346 Kcal and 9.86-40.91 $\mathrm{g}$, while calcium and iron content of selected herbs ranged between $80.0-2112.5 \mathrm{mg} / 100 \mathrm{~g}$ and $2.75-87.4 \mathrm{mg} / 100 \mathrm{~g}$ respectively.

\section{Organoleptic evaluation of developed rice flakes mix}

Table 3, shows the organoleptic scores of rice flakes mix prepared by utilizing selected dehydrated herbs. The treatment $\mathrm{T}_{4}(16 \%$ incorporation) of the product was found to be highly acceptable with scores $8.80,8.80,8.75,8.65$ and 8.77 for color, texture, flavor, taste and overall acceptability than control $\left(\mathrm{T}_{0}\right)$, making it quite obvious that the addition of $16 \%$ dehydrated herbs, increase the color, consistency, flavor, taste and overall acceptability of the rice flakes mix. The other levels of incorporation were also liked at various degrees although a little less than $\mathrm{T}_{4}$. Analysis of variance (ANOVA) reveals that the calculated value of $F$ (15.85) is greater than table value (3.26) on 4,12 (d.f.) at $5 \%$ probability level. Therefore it can be concluded that there was a significant difference $(\mathrm{p} \leq 0.05)$ between treatments regarding the overall acceptability of the product. Herbs have antimicrobial property and it act as traditional food preservative, which increases the shelf life of the product $[14,15]$.

\section{Nutritive value of developed rice flakes mix}

The data pertaining to nutritive value of the developed herbal rice flakes mix is presented in table 4 . The maximum energy value 346 $\mathrm{Kcal} / 100 \mathrm{~g}$ was observed in treatment $\mathrm{T}_{0}$ (control) which had energy

\begin{tabular}{|c|c|c|c|c|c|c|c|c|c|c|}
\hline S.No & Local name & Botanical name & Moisture (g) & Fat (g) & Protein (g) & Carbohydrate (g) & Energy (Kcal) & Fiber $(g)$ & Calcium (mg) & Iron (mg) \\
\hline 1. & Mint (leaves) & Mentha asiatica & $11.3 \pm 0.05$ & $5.91 \pm 0.02$ & $19.85 \pm 0.02$ & $51.5 \pm$ & $285 \pm 0.28$ & $29.63 \pm 0.08$ & $1486.8 \pm 0.72$ & $87.4 \pm 0.05$ \\
\hline 2. & aves) & Ocimı & $6.43 \pm 0.01$ & 3. & $.01 \pm 0.04$ & \pm 0.18 & 0.33 & \pm 0.04 & $2112.5 \pm 0.28$ & 0.28 \\
\hline 3. & Drumstick (leaves) & Moringa oligfera & $7.45 \pm 0.02$ & $2.25 \pm 0.02$ & $27.06 \pm 0.03$ & $38.1 \pm 0.01$ & $205 \pm 0.16$ & $19.1 \pm 0.05$ & $2002.5 \pm 0.28$ & $28.11 \pm 0.07$ \\
\hline 4. & Ginger (root) & Zingiber officinale & $9.38 \pm 0.00$ & $5.8 \pm 0.05$ & $9.06 \pm 0.02$ & $70.7 \pm 0.05$ & $346 \pm 0.43$ & $12.46 \pm 0.01$ & $115.5 \pm 0.28$ & $11.5 \pm 0.02$ \\
\hline 5. & Garlic (cloves) & Allium longicuspis & $5.20 \pm 0.17$ & $0.76 \pm 0.00$ & $16.8 \pm 0.05$ & $72.71 \pm 0.00$ & $332 \pm 0.57$ & $9.86 \pm 0.02$ & $80.0 \pm 1.15$ & $2.75 \pm 0.01$ \\
\hline 6. & Lotus (stem) & Nelumbo nucifera & $9.45 \pm 0.02$ & $1.29 \pm 0.00$ & $4.06 \pm 0.02$ & $51.3 \pm 0.05$ & $234 \pm 0.28$ & $24.6 \pm 0.16$ & $127.8 \pm 0.15$ & $60.55 \pm 0.02$ \\
\hline
\end{tabular}

Values are expressed as means $\pm \operatorname{SEM}(n=3)$. 
Citation: Gupta E, Sinha J, Dubey RP (2012) Utilization of Dehydrated Herbs in the Formulation of Value Added Snack "Rice Flakes Mix". J Food Process Technol S1-002. doi:10.4172/2157-7110.S1-002

Page 3 of 4

\begin{tabular}{|c|c|c|c|c|c|}
\hline \multirow{2}{*}{ Sensory characteristics/Treatments } & \multicolumn{5}{|c|}{ Scores on 9 point hedonic scale } \\
\hline & Color & Texture & Flavor & Taste & Overall acceptability \\
\hline $\mathrm{T}_{0}$ (Control) & $7.55 \pm 0.20$ & $7.65 \pm 0.22$ & $7.65 \pm 0.15$ & $7.55 \pm 0.15$ & $7.60 \pm 0.15$ \\
\hline $\mathrm{T}_{1}(4 \%)$ & $8.25 \pm 0.25$ & $8.40 \pm 0.21$ & $8.10 \pm 0.10$ & $8.05 \pm 0.09$ & $8.20 \pm 0.16$ \\
\hline $\mathrm{T}_{2}(8 \%)$ & $8.45 \pm 0.22$ & $8.40 \pm 0.21$ & $8.15 \pm 0.15$ & $8.25 \pm 0.09$ & $8.31 \pm 0.16$ \\
\hline $\mathrm{T}_{3}(12 \%)$ & $8.20 \pm 0.24$ & $7.95 \pm 0.09$ & $7.65 \pm 0.17$ & $7.85 \pm 0.29$ & $7.91 \pm 0.13$ \\
\hline $\mathrm{T}_{4}(16 \%)$ & $8.80 \pm 0.14$ & $8.80 \pm 0.14$ & $8.75 \pm 0.12$ & $8.65 \pm 0.23$ & $8.77 \pm 0.11$ \\
\hline F value & $7.45^{*}$ & $10.69^{*}$ & $10.8^{*}$ & $5.05^{*}$ & $15.85^{\star}$ \\
\hline C.D. $(P=0.05)$ & 0.4200 & 0.3435 & 0.346 & 0.4628 & 0.2786 \\
\hline
\end{tabular}

9-point hedonic scale is as follows: 1-dislike extremely, 2-dislike very much, 3-dislike moderately, 4-dislike slightly, 5-neither like or dislike, 6-like slightly, 7-like moderately,

8-like very much, 9-like extremely.

* -Significant difference is at 0.05 levels

Values are expressed as means \pm SEM

Table 3: Average organoleptic scores of different parameters in control and treated sample of rice flakes mix.

\begin{tabular}{|c|c|c|c|c|c|c|c|}
\hline \begin{tabular}{|c|} 
Nutrients \\
Treatments
\end{tabular} & Fat $(\mathrm{g})$ & Protein $(\mathbf{g})$ & Carbohydrate (g) & Energy (Kcal) & Fiber $(\mathbf{g})$ & Calcium (mg) & Iron (mg) \\
\hline$T_{0}$ & 1.20 & 6.60 & 77.30 & 346 & 0.70 & 20.00 & 20.00 \\
\hline$T_{1}$ & 1.28 & 6.82 & 76.66 & 344 & 1.44 & 40.09 & 20.81 \\
\hline$T_{2}$ & 1.27 & 6.67 & 75.72 & 339 & 2.52 & 61.74 & 21.97 \\
\hline$T_{3}$ & 1.26 & 6.70 & 74.46 & 334 & 3.28 & 76.04 & 23.45 \\
\hline$T_{4}$ & 1.34 & 6.86 & 73.53 & 330 & 4.46 & 119.35 & 25.16 \\
\hline
\end{tabular}

Table 4: Nutrient composition (per $100 \mathrm{~g}$ ) in control and treated sample of rice flakes mixes.

rich ingredient like rice flakes. On comparing the protein content it was found to be highest in treatment $\mathrm{T}_{4}(6.86 \mathrm{~g} / 100 \mathrm{~g})$. Fat content was improved in treatment $\mathrm{T}_{4}(1.34 \mathrm{~g} / 100 \mathrm{~g})$ in comparison to treatment $\mathrm{T}_{0}$ (control) $\left(1.20 \mathrm{~g}\right.$ ), carbohydrate content of treatment $\mathrm{T}_{0}$ (control) $(77.30 \mathrm{~g} / 100 \mathrm{~g})$ was maximum and minimum for treatment $\mathrm{T}_{4}(73.53$ g). Fiber in treatment $\mathrm{T}_{4}(4.46 \mathrm{~g} / 100 \mathrm{~g})$ was in the highest amount. The treatment $\mathrm{T}_{0}$ (control) in general had low fiber content whereas after the incorporation of dehydrated herbs, the values increased considerably. Thus, the developed rice flakes mix can be recommended to persons requiring high fiber diets. The calcium content was found to be maximum in treatment $\mathrm{T}_{4}(119.35 \mathrm{mg} / 100 \mathrm{~g})$ among other treatments. The range of iron content in developed rice flakes mix was 20.0 to 25.16 $\mathrm{mg} / 100 \mathrm{~g}$. The increase in iron values can be said to be proportionate to the quantities of dehydrated herbs added to the main ingredient rice flakes [16]. The rice flakes mix can therefore be recommended for intervention among anemic subjects as well as among others for improving nutritional status of the population. The standard rice flakes mix available in the market have low nutritional value in comparison to the developed rice flakes mix incorporated with dehydrated herbs.

\section{Conclusion}

It can be concluded from the results that the incorporation of selected dehydrated herbs (viz. mint, basil, drumstick leaves, ginger, garlic and lotus stem) in rice flakes can improve the nutritional quality of products and adds variety in the diet. The dehydrated herbs used in preparation of rice flakes mix act as antimicrobial agent, which works as a natural preservative to keep food safe and to increase the shelf life of the product. Partial replacing of rice flakes with dehydrated herbs had good impact on the nutritive value by increasing the protein, fat, fiber, calcium and iron content in the rice flakes mix. The prepared herbal rice flakes mix was found to be acceptable in both sensory and nutritional quality. Thus addition of value added edible medicinal herbs in food products will improve the well being of the citizen in the country and prevent micronutrient malnutrition.

\section{Acknowledgement}

I owe a never ending debt of gratitude to my adored and worshipful God for his grace in the completion of the study. I grateful acknowledge to Dr. Ritu Dubey for her great support during my research work.

\section{References}

1. Boutelle KN, Birnbaum AS, Lytle LA, Murray DM, Story M (2003) Associations between perceived family meal environment and parent intake of fruit, vegetables, and fat. J Nutr Educ Behav 35: 24-29.

2. Neumark SD, Story M, Ackard D, Moe J, Perry C (2000) The 'Family Meal': Views of Adolescents. J Nutr Educ 32: 329-334.

3. Pollitt E, Gersovitz M, Gargiulo M (1978) Educational benefits of the United States school feeding program: a critical review of the literature. Am J Public Health 68: 477-481.

4. Winston JC (1999) Health-promoting properties of common herbs. Am J Clin Nutr 70: 491S-499S

5. Shelef LA (1984) Antimicrobial Effects of Spices. J Food Safety 6: 29-44

6. Fisher C (1992) Phenolic Compounds in Spices. In: Phenolic Compounds in Food and Their Effects on Health I. ACS Symposium Series, USA

7. Suppakul P, Miltz J, Sonneveld K, Bigger SW (2003) Antimicrobial properties of basil and its possible application in food packaging. J Agric Food Chem 51 3197-3207.

8. Lai PK, Roy J (2004) Antimicrobial and chemopreventive properties of herbs and spices. Curr Med Chem 11: 1451-1460.

9. Flyman MV, Afolayan AJ (2006) The suitability of wild vegetables for alleviating human dietary deficiencies. S Afr J Bot 72: 492-497.

10. Lee KH (2000) Research and future trends in the pharmaceutical development of medicinal herbs from Chinese medicine. Public Health Nutr 3: 515-522.

11. Cunniff $P$ (1995) Official methods of analysis of AOAC international. (16th edn) Association of Official Analytical Chemists, USA

12. Ranganna S (2001) Hand Book of Analysis and Quality Control for Fruits and Vegetable Products, Seventh edition, Tata McGraw Hill Book Co., New Delhi, India, 594-625.

13. Gopalan C, Shastri BVP, Balasubramanium SC (2004) Nutritive value of Indian foods, $1^{\text {st }}$ edition, NIN (ICMR), Hyderabad, India, 48-61.

14. Kaefer CM, Milner JA (2008) The role of herbs and spices in cancer prevention. J Nutr Biochem 19: 347-361. 
Citation: Gupta E, Sinha J, Dubey RP (2012) Utilization of Dehydrated Herbs in the Formulation of Value Added Snack "Rice Flakes Mix". J Food Process Technol S1-002. doi:10.4172/2157-7110.S1-002

Page 4 of 4

15. Prakash P, Gupta N (2005) Therapeutic use of Ocimum sanctum Linn (Tulsi) with a note on eugenol and its pharmacological actions: a short review. Indian J Physiol Pharmacol 49: 125-131.
16. Suma RC, Sheetal G, Jyothi LA, Prakash J (2007) Influence of phytin phosphorous and dietary fibre on in vitro iron and calcium bioavailability from rice flakes. Int J Food Sci Nutr 58: 637-643. 